\title{
The fusion of Dragon Boat Sports and sports tourism operators The Belt and Road Initiative
}

\author{
Hong-chun $\mathrm{Jia}^{1}$, Song-bo $\mathrm{He}^{1, *}$, Ying-yu $\mathrm{Miao}^{2}$ \\ ${ }^{1}$ Beihua University ,Jilin, China \\ ${ }^{2}$ Beihua University, College of physical education, Longteng innovation and entrepreneurship \\ education base \\ *Corresponding author
}

Keywords: Belt and Road Initiative; Dragon Boat Sports; sports tourism

\begin{abstract}
July 6, 2017, the National Tourism Bureau, the State Sports General Administration jointly issued the "The Belt and Road" sports tourism development action plan "," plan "stressed that through the interaction of sports tourism to promote the full range of The Belt and Road" within the area of communication, communication and industrial policy people connected to the sports tourism has become "open cooperation The Belt and Road regional highlights. Dragon Boat Festival is a traditional sports activities by the Chinese people's favorite. It has a national, artistic, technical, competitive, and interest groups and other characteristics, the city sports tourism publicity, with the help of Dragon Boat Sports Marketing, will become a new growth point of regional economic development, the dragon boat tournament operations and sports tourism integration will promote tourism and leisure sports related areas of great development.

The national sports tourism industry development conference held in July 6, 2017, the National Tourism Bureau, the State Sports General Administration jointly issued the "The Belt and Road" sports tourism development action plan ". "Plan" pointed out that sports tourism is a new form of industry integration of sports industry and tourism industry in depth, vigorously develop the sports tourism is the inevitable requirement of rich tourism products, expand tourism consumption space, promote the transformation and upgrading of the tourism industry, is the inevitable choice of vitalizing sports resources, to achieve fitness and health, promote the depth of integration of sports industry upgrading efficiency, to foster new economic development momentum, expand new space for economic development has very important significance. "Belt and Road Initiative along the countries and regions with rich resources of sports tourism, sports tourism development potential.
\end{abstract}

\section{Characteristics of sports tourism in China}

Sports tourism is a sports activity has naturally led to the casual nature of strong participation or watching sport event tourists according to the benefit maximization principle: in the space has completed its own displacement (possibly remote space displacement) under the condition of the majority of people would choose other joint activities of tourism is one of the most easily derived popular activities to watch the game so naturally with the combination of tourism activities for comprehensive tourism activities, tourism, leisure, shopping, watching as a whole, the sports event tourism in the previous World Cup or the Olympic Games have a large number of visitors to the games and events around the city leisure sports tourism.

\section{The value and advantages of Dragon Boat Sports into sports tourism}

\section{1 .Cultural and educational values}

Dragon boat culture is an important component of dragon culture, which embodies special cultural values in the development of modern social culture. The dragon boat culture of God from 
the memorial to the development of the hero of the memorial, it embodies people's psychology of love and attachment of the nation, the people's pursuit of spiritual life, the life of hope for a better future of national identity. The process of national identity is the process of social education, the culture of Dragon Boat Dragon Boat races will be the essence of culture performance, so that the masses to further understand the national hero that refuse to be cowed or submit national integrity, to accept the influence of traditional Chinese culture, education.

\section{Exchange value}

Since the State Sports General Administration approved the dragon boat race as a formal event, the dragon boat race came out of the local and regional folk customs and became the common traditional culture of the Chinese nation. China is the hometown of dragon boats. There are many dragon boat lovers abroad who come to China every year to participate in or watch the matches, and to experience the auspicious atmosphere of dragon boats. At present, there are dragon boat races in France, the United States, Australia and other countries. Italy, Sweden, India, Holland and other countries also use dragon boat racing as a window to understand china. With more and China traditional culture of Dragon Boat Sports Influence in the world within the scope of the larger, with the Dragon Boat Race of domestic and international exchanges have become increasingly frequent, dragon boat racing has internationalization, promote friendship with the people of the world China people.

\section{Economic value}

The dragon boat race to today, in a unique form of a strong impact on the public and society, has become a cultural phenomenon in the Dragon Boat Sports, fitness, entertainment, tourism, commercial integration. The Dragon Boat Festival the Dragon Boat flower, dragon boat, dragon boat, Dragon Temple dinner party and other activities, attracts people from all walks of life to drive the regional economic development.

\section{Dragon Boat Invitational Tournament tourism development strategy}

\section{Strengthen theoretical research, enrich cultural background, and enhance development potential}

The development of any tourism resources should have a rich cultural background, which is the basis of tourism development. The Dragon Boat Sport Development for many years, but the lack of theoretical research on dragon boat culture, when we have a thing's origin, development, economic and social value to study clearly, so the development of this thing just castles in the air, miles away. The Dragon Boat Sport theoretical article less, research articles limited only from the dragon to carry out the status quo, influencing factors, only the depth of mining Dragon Boat folk sports culture resources, to promote the development of Dragon Boat Sports and related tourism industry.

\section{Pay attention to the cultivation and introduction of talent, and develop human resources}

The major of sports tourism should have the quality of modern enterprise management, be familiar with sports management rules and be familiar with the laws of market economy. Secondly, with sufficient knowledge of tourism, can play a role in guiding and encouraging public participation in the popularization of the project, and play an ambassador role in the promotion of dragon boats. Therefore, on the one hand, we should cultivate local folk sports talents with the help of local universities. On the other hand, the introduction of domestic and foreign successful experience in the development of folk sports tourism and high quality professional talents, learn from the successful case of Beijing, Shanghai to build the brand of major international events, promote the development of Dragon Boat Festival tourism.

\section{To meet the needs of social development, establish the concept of event management}

At present, the "dragon boat up the stage, singing and trade win-win idea" has become the consensus of the country, by means of the dragon boat race can bring huge economic and social benefits for the local. At present, the dragon boat race is mainly managed by means of related performances to attract tourists, thereby stimulating the consumption of local related industries. In addition, it is difficult to see other modes of operation, such as dragon boat race, brand building, Dragon Boat tourism, technology research and development of goods and so on. Explain the lack of 
local government and public awareness of business events. Therefore, we should vigorously establish the concept of the management of the government and the people through various channels, so that the development of the dragon boat race can be implemented.

\section{Pay attention to the intermediary role of sports market, and promote the development of the tourism industry}

The sports competition market intermediary between government, market competition is the main operation, supply and demand event event services between the parties, and the individual or organization communication, coordination, supervision, assessment, brokerage, trading and information services in the activities to improve the operational efficiency of sports market. However, many regions do not know enough about the market resources, especially the tourism resources. They are not aware of the importance of the intermediary institutions, and exist in the development of dragon boat tourism resources out of market behavior. Therefore, effective measures should be taken to establish a sound cooperative relationship with the intermediary so as to promote the vigorous development of the Dragon Boat movement.

\section{5 , take dragon boat as the carrier, develop recreational sports tourism industry on water}

Leisure sports tourism is a new industry in our country, and its development speed is amazing. The areas where dragon boats are developed are rich in water resources. Therefore, we should make full use of these advantageous resources and develop the water tourism industry with dragon boat as the carrier. For example, to carry out the marine fishing, water skiing, diving, motorboat ocean with water for a variety of large-scale international resources activities; the development of all kinds of diving, water polo, swimming and other water leisure sports; development of water to the theme of leisure sports theme park; create China Water leisure sports tourism destination image through a pro series water sports tourism products.

\section{Conclusion}

The national traditional sports culture of our country has experienced the impact of western sports culture for more than one century, and there has been a cultural crisis. Now, with the enhancement of national strength, the time has come to revive the traditional sports culture of the Chinese nation. The dragon boat sport is the essence of Chinese traditional sports culture, protection, inheritance and development, promote the culture of Dragon Boat Dragon Boat Sport, both sports and folk worker's responsibility, but also the people's practical requirements, is to promote The Belt and Road, will need to carry forward the traditional culture. With the help of The Belt and Road vigorously develop the leisure sports tourism, which is conducive to better inherit the Chinese nation unremitting self-improvement, solidarity, forge ahead of excellent quality; at the same time, the image of the sports tourism has very important significance to enhance the cultural quality of the city.

\section{Acknowledgements}

This paper is a research project of Beihua University students' innovation project, horizontal topi c: Dragon Boat land training equipment (NO:201602014).

\section{Reference}

[1] Yang Shuangyan, Zhang Hongmei, on the cultural dissemination of national folk sports events under the background of "2014 Youth Olympic Games" [J], sports science and Technology Bulletin, 2014, 22

[2] Qin wei. Dragon Boat Racing [M], Beijing: Chinese social press, 2010.

[3] Huang Haiyan, Zhang Lin, cultivation and development of intermediary services in sports market [J], Journal of Wuhan Sports Institute, 2007, 41

[4] Wang Luyi, Zou Shi, urban leisure culture and regional leisure industry: a case study of Wuhan 
urban leisure culture resources [[J]. natural dialectics, 2006,22,

[5] Yu Shouwen, the sports industry and city competitiveness M]. Shanghai: Fudan University press, 2008:31-32.

[6] Gao 6. Study on the analysis and selection of leisure sports industry development strategy in Wuhan city circle [[J]. Journal of Xianning University, 2011,6.

[7] Chen Yan, maritime Silk Road and cultural exchanges between China and foreign countries [M], Beijing: Peking University press, 1996 